\title{
DEHULLING CHARACTERISTICS OF OAT (OL-9 VARIETY) AS AFFECTED BY GRAIN MOISTURE CONTENT
}

\author{
Jaspreet Kaur ${ }^{1}$, Amarjeet Kaur ${ }^{2}$, Poonam Aggarwal ${ }^{3}$ \\ ${ }^{1}$ Ph.D. scholar, Department of Food Science and Technology, Punjab Agricultural University, Ludhiana- 141004, \\ Ludhiana, Punjab, India \\ ${ }^{2}$ Senior Milling Technologist-cum-Head, Department of Food Science and Technology, Punjab Agricultural \\ University, Ludhiana- 141004, Punjab, India \\ ${ }^{3}$ Senior Vegetable Technologist, Department of Food Science and Technology, Punjab Agricultural University, \\ Ludhiana- 141004, Ludhiana, Punjab, India
}

\begin{abstract}
Dehulling of oat is difficult and inefficient process. Moisture content of grains is one of the most important factors that affects dehulling. Dehulling parameters of oat grains (OL-9) were studied by varying grain moisture contents at 10, 13, 16 and 19, percent. Dehulling was achieved using an indigenously developed small scale impact oat dehuller. Groat recovery (\%) and dehulling efficiency $(D H E)$ significantly $(P \leq 0.05)$ increased as grain moisture was increased from 10 to 16 percent. However, broken content $(\%)$ significantly $(P \leq 0.05)$ decreased as grain moisture was increased from 10 to 19 percent. Hence, 16 per cent grain moisture was considered optimum for impact dehulling of oat grains. Second order regression equations were developed to help relate grain moisture to various dehulling parameters.
\end{abstract}

Keywords: Oat, Dehulling efficiency, Groat recovery, Broken, Regression

\section{INTRODUCTION}

Oats (Avena sativa) have been used both as food and feed for the last one thousand years. They have been considered as poor man's food and used mainly as porridge, oat meal etc. In recent times there has been renewed and increased interest in use of oats as health food because of the excellent nutritional and functional properties. Oats contain lipids that are rich in unsaturated fats (about 80 percent) and essential fatty acids like linoleic acid. Oats contain unique antioxidants, called avenanthramides, as well as the vitamin E-like compounds, tocotrienols and tocopherols [1]. Oat protein contains considerable quantities of essential amino acids in comparison to wheat [2, 3]. They are an excellent source of soluble fiber in the form of beta-glucan. Beta glucan is found in the cell walls in oats, has excellent functional properties and is well known for lowering serum cholesterol and blood sugar.

Oat grain consists of outer covering called hull or husk that comprises $25-30 \%$ of the weight of the oat grain [2]. It is mainly composed of cellulose, hemicellulose and lignin [4]. It is inedible and not digested by humans and should be removed from oats. Dehulling may be achieved by various methods such as manual peeling, stone dehulling, impact dehulling and compressed air dehulling [5]. These methods vary in efficiency and groat recovery depends upon the dehulling conditions [6]. In developing countries such as India, where oat is still mainly considered as a feed crop, there is dearth of technology for efficient dehulling and milling. Most of the market in the developing world depends on imported oat flakes and products. Although, oat grain may be dehulled using traditional methods, these are highly inefficient and result in high level of hull fraction in flour which is detrimental to quality of flour and resulting products.

Impact hulling is one of the most widely used industrial method for removing the resilient, inedible hulls that cover the groat [7]. Oats are fed through a hopper to the centre of a rotor that is equipped with vanes or blades. The oats are thrown against an impact ring made of rubber, steel, plastic or composite material, that is attached to the housing of the machine [7,8]. Rotor speed has to be adjusted as higher speed may lead to breakage of hull [9].

This investigation was carried out to standardize the dehulling of oat grains into groats using indigenously developed oat dehuller. This was done by adjusting the moisture content of the grains and studying its affect on the dehulling parameters such as brokens, dehulling efficiency and groat yield.

\section{MATERIALS AND METHODS}

\subsection{Procurement of Grains}

Oat grains (OL-9) grown in the year 2012-13 were procured from Punjab Agricultural University, Ludhiana. Grains were cleaned using various cleaning techniques to remove dust, straw, stalks, stones etc. They were stored at room temperature $\left(10 \pm 2^{\circ} \mathrm{C}\right)$ in plastic bins. 


\subsection{Physical Grain Characteristics}

Oat grains were assessed for physical parameters such as thousand grain weight, hectolitre weight and bulk density using AACC procedures [10]. Colour values in terms of $L^{*}$ value, hue and chroma were assessed using Hunter Lab Scan XE (Hunter Associates Laboratory Inc., Reston, Virginia, USA) (NR-3000; 10\%/D65). $L^{*}$ value represents lightness (0-100).

\subsection{Conditioning of Grains}

Initial moisture content of grains was observed using hot air oven by AACC method [10]. Grains were conditioned by sprinkling distilled water on known weight of grains and storing them overnight in covered plastic bins in refrigerated conditions $\left(4-10{ }^{\circ} \mathrm{C}\right)$. Oat grains were subjected to conditioning at 10,13,16 and 19\% moisture. Conditioning was done using the formula [11] as below:-

$$
W_{m}=W_{1}\left[\frac{\Delta M}{100-M_{2}}\right]
$$

Where $\mathrm{Wm}$ is moisture to be added or removed $(\mathrm{g}), \mathrm{W}_{1}$ is initial weight of the seed at $M_{1}(g), \Delta M=M_{2}-M_{1}$ (for $M_{2}>M_{1}$ ) and $\Delta \mathrm{M}=\mathrm{M}_{1}-\mathrm{M}_{2}$ (for $\mathrm{M}_{1}>\mathrm{M}_{2}$ ), $\mathrm{M}_{1}$ is initial moisture content (wb) and $\mathrm{M}_{2}$ is final or desired moisture content (wb).

\subsection{Dehulling of Oat Grains}

Oat grains were dehulled as per Fig-1. Conditioned grains were fed into an impact dehuller (Lab Impact 1, M/s Creative India Pvt. Ltd., Mohali). Grains were continuously fed through the hopper. These were made to strike against the blades of a fan that operated at high speed (2100 rpm). The high speed impact caused the hull to break open, thus releasing the groats. The mixture of groats and separated hull was obtained at an outlet below. Mixture of groats, hull and undehulled grains were passed through the system two more times.

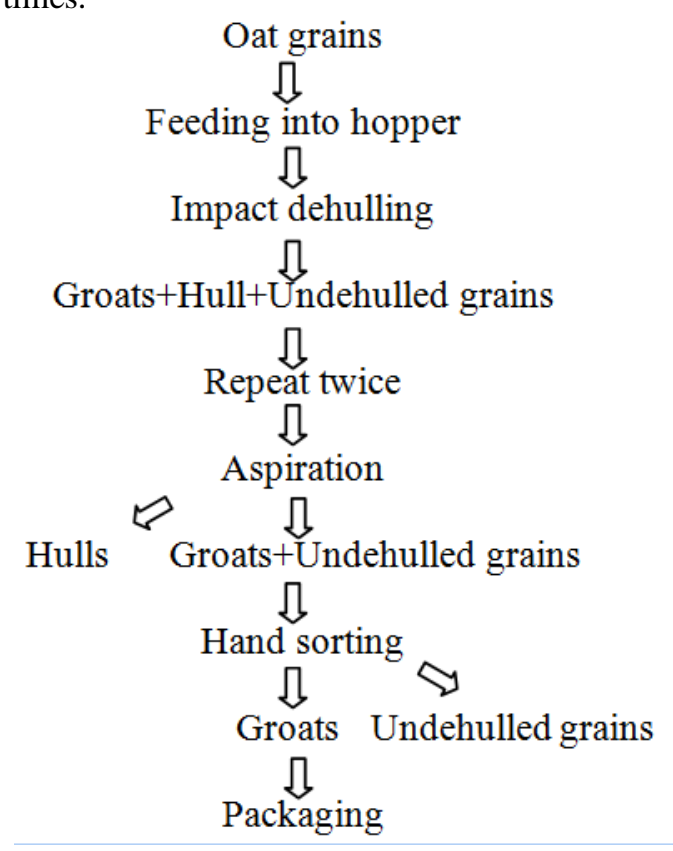

Fig-1: Flow diagram for dehulling of oat grains
Finally, the mixture was collected at the bottom and fed twice into Laboratory Aspirator. Some amount of hull and undehulled grains were still found mixed with the groats. These were hand sorted later. Samples were sealed in polyethylene bags (Fig-2) and stored till further sorting and processing.

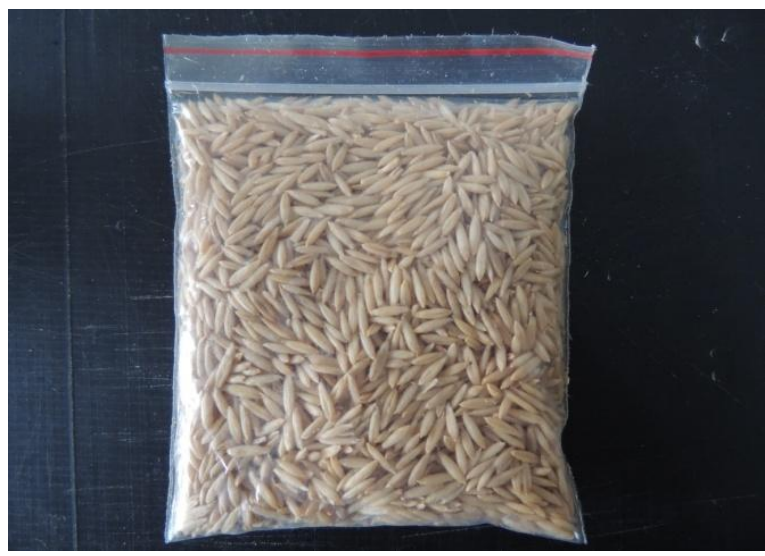

Fig-2: Packaged groats

In order to account for the changes in moisture content during this period, moisture correction factor (MCF) was applied [5].

$$
\mathrm{MCF}=\frac{\text { Original groat preparation } \text { mass }}{\text { Current groat preparation mass }}
$$

After hand sorting, sample was classified as intact groats, broken, husk and undehulled oats.

Dehulling efficiency (DHE, the portion of oats dehulled through the oat dehuller), groat $\%$ and broken $(\% \mathrm{~B})$ were calculatedas given below [5]:-

$$
\begin{aligned}
& \mathrm{DHE}=\frac{100\lfloor\mathrm{WO}-(\mathrm{R} \times \mathrm{MCF})\rfloor}{\mathrm{WO}} \\
& \% \text { Groat }=\frac{100\lfloor(\mathrm{G}+\mathrm{B}) \times \mathrm{MCF}\rfloor}{\mathrm{WO}-(\mathrm{R} \times \mathrm{MCF})} \\
& \% B=\frac{100 \times B}{(G+B)}
\end{aligned}
$$

Where WO is the whole oat mass fed to the dehuller, $\mathrm{R}$ is the mass of the hulled oats remaining, $G$ is the mass of the unbroken groats, and B is the mass of the broken groats.

\subsection{Statistical Analysis}

Data obtained was analyzed statistically using techniques of analysis of variance [12]. All statistical procedures were performed using SPSS (version 16.0) SPSS Inc (Chicago, USA). A one-way analysis of variance (ANOVA) was carried out using completely randomized design and the means were compared using Duncan's Multiple Range Test at $P \leq 0.05$. The results are presented as means \pm S.D. (standard deviation) of triplicate analyses. 


\section{RESULTS AND DISCUSSION}

\subsection{Physical Properties of Grains}

Oat grains (OL-9 variety) were assessed for physical parameters (Table 1). Grains were long and slender with thousand grain weight of $29.143 \pm 0.081 \mathrm{~g}$. Bulk density is an important parameter that is correlated with dehulling efficiency (DHE) [13].

Table-1 Physical properties of oat grains (OL-9)

\begin{tabular}{|l|l|}
\hline Physical property & Value \pm S.D. \\
\hline Grain length $(\mathrm{mm})$ & $15.333 \pm 0.577$ \\
\hline $\begin{array}{l}\text { Thousand grain } \\
\text { weight }\end{array}$ & $29.143 \pm 0.081 \mathrm{~g}$ \\
\hline Bulk density & $47.927 \pm 0.006 \mathrm{gml}^{-1}$ \\
\hline Hectolitre weight & $45.533 \pm 0.153$ \\
\hline Lightness & $66.737 \pm 0.341$ \\
\hline Hue & $1.258 \pm 0.005$ \\
\hline Chroma & $7.716 \pm 0.172$ \\
\hline
\end{tabular}

S.D.: standard deviation

\subsection{Dehulling Parameters}

The effect of moisture content was studied on DHE, groat $\%$ and broken $\%$.

\subsubsection{DHE}

DHE is one of the most important parameters from the financial point of view. It is imperative for economic success of any milling plant [14,15]. Moisture content of oat grains had significant ( $\mathrm{p} \leq 0.05$ ) effect on DHE (Table 2).

Table-2: Analysis of variance for dehulling characteristics as affected by grain moisture

\begin{tabular}{|l|l|l|l|l|l|}
\hline Source & $\begin{array}{l}\text { Sum of } \\
\text { squares }\end{array}$ & $\begin{array}{l}\text { Degree } \\
\text { of } \\
\text { freedom }\end{array}$ & $\begin{array}{l}\text { Mean } \\
\text { square }\end{array}$ & F-value & $\begin{array}{l}\text { p- } \\
\text { value }\end{array}$ \\
\hline DHE* $^{*}$ & 282.858 & 3 & 94.286 & 87.425 & 0.000 \\
\hline Groat & 119.771 & 3 & 39.924 & 30.732 & 0.000 \\
\hline Broken & 67.655 & 3 & 22.552 & 155.368 & 0.000 \\
\hline
\end{tabular}

*Dehulling efficiency

As is observed in Fig 3, increase in grain moisture from 10 to $16 \%$ caused a sharp increase in DHE. However, DHE showed a slight drop as moisture was further increased to $19 \%$. This trend may be because of greater moisture absorption by inner groats than the hull. Subsequently, groat mass increases. This difference in mass facilitates easier separation of hull from groat during impact dehulling.

Table-3: Second order equations and dehulling parameters in terms of moisture content of grains

\begin{tabular}{|l|l|l|}
\hline $\begin{array}{l}\text { Dehulling } \\
\text { parameter }\end{array}$ & Equation & $\mathbf{R}^{2}$ \\
\hline DHE* & $\mathrm{y}=-1.5171 \mathrm{x}^{2}+11.523 \mathrm{x}+64.375$ & 0.919 \\
\hline Broken $(\%)$ & $\mathrm{y}=0.9416 \mathrm{x}^{2}-6.654 \mathrm{x}+14.037$ & 0.997 \\
\hline Groat $(\%)$ & $\mathrm{y}=-0.024 \mathrm{x}^{2}+2.6292 \mathrm{x}+58.031$ & 0.789 \\
\hline
\end{tabular}

*Dehulling efficiency
Table-3 shows a quadratic regression equation between dehulling efficiency and moisture content. DHE was strongly correlated with grain moisture $\left(\mathrm{R}^{2}=0.919\right)$.

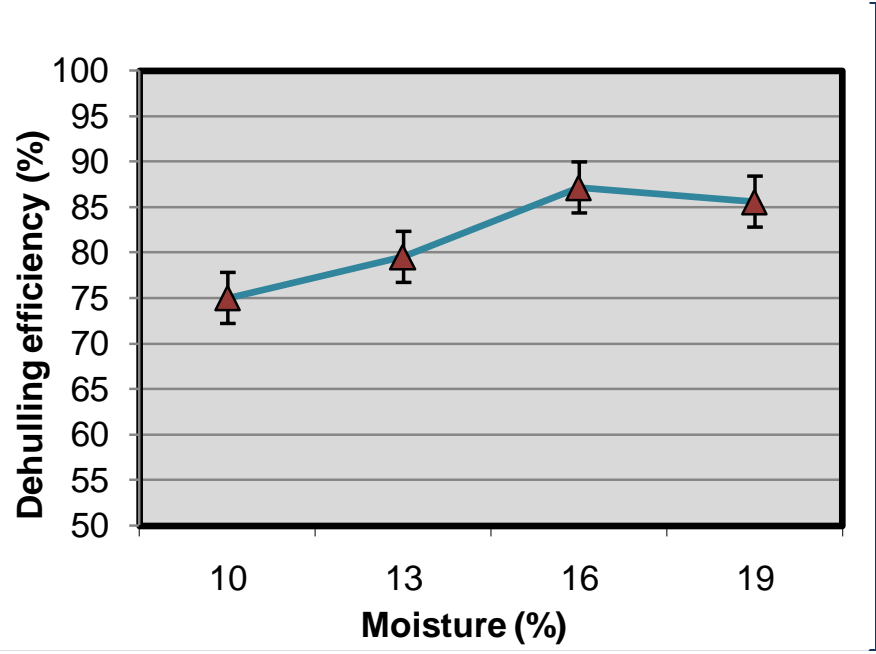

Fig-3 Effect of grain moisture on dehulling efficiency

\subsubsection{Groat $\%$}

Increase in groat \% was observed when moisture was increased from 10 to 16 per cent (Fig-4). A steep rise in groat $\%$ was observed when moisture was increased from 13 to $16 \%$. With further increase in moisture, groat $\%$ was more or less stable. Table-2 shows a significant $(\mathrm{p} \leq 0.05)$ effect of grain moisture on groat \%. Groat recovery (groat $\%)$ was also correlated to grain moisture $\left(\mathrm{R}^{2}=0.789\right)$ (Table-3).

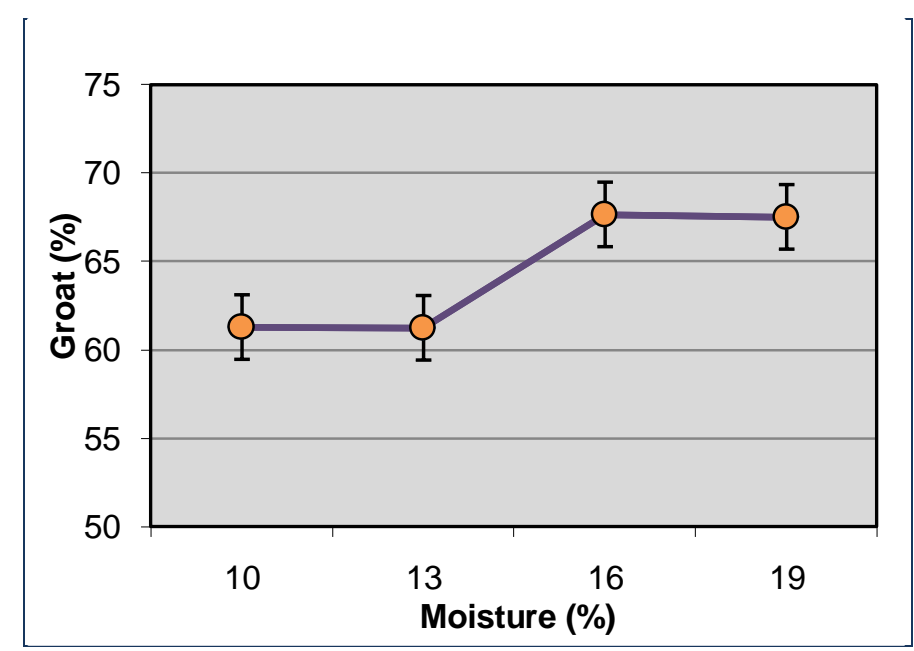

Fig-4: Effect of grain moisture content on groat $\%$

\subsubsection{Broken\%}

Higher percentage of broken groats is unacceptable as it increases the susceptibility to storage pests [16]. However a falling trend was observed in broken content with increase in moisture (Fig-5). An increase in grain moisture caused significant reduction $(\mathrm{p} \leq 0.05)$ in broken content (Table-2). Broken content may also be strongly correlated with moisture content of grain $\left(\mathrm{R}^{2}=0.997\right)($ Table-3). 


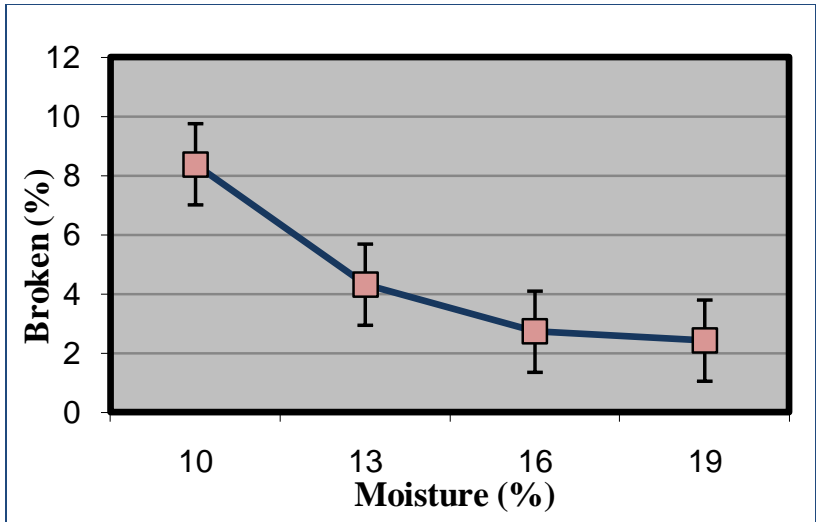

Fig 5: Effect of grain moisture on broken\%

Doehlert and McMullen also observed a decrease in broken $\%$ as moisture was increased from $7.5-30 \%$ [5]. The regression equations may help to relate grain moisture to various dehulling parameters via second order equations (Table 3) and help in predicting dehulling behaviour of oat grains.

From the data obtained, it may be inferred that grain moisture is an important factor during dehulling of oat grains. While using indigenously developed oat dehulling technology, increase in grain moisture to $16 \%$ led to significant improvement in DHE and groat yield. Beyond this there was no significant increase in dehulling parameters. It was thus considered optimum for dehulling of oats by this technology of impact dehulling.

Oat dehulling is more difficult than other grains as hull is more strongly attached to the groat. Certain oat grains were resistant to dehulling due to different physical characteristics. According to Doehlert et al, grains with lower bulk density and lower linear dimensions resist dehulling more than their counterparts [17]. The dehulled oats/groats can be milled in a traditional atta chakki. The resultant flour would be rich in functional ingredients found in oat bran as well as endosperm such as beta-glucan, essential fatty acids and antioxidants such as avenanthramides. Indigenously developed dehulling technology would thus be able to solve the problem of small-scale oat processors who were unable to produce high grade oat flour to serve the fast emerging oat processing industry in developing countries such as India.

\section{CONCLUSIONS}

Moisture content of grains had significant effect on dehulling efficiency, groat $\%$ and broken $\%$. Whole groats were obtained with lower broken percentage at $16 \%$ grain moisture content. By standardization of oat dehulling process on indigenously developed oat dehuller, grains can be dehulled even at a small scale. Further studies on optimizing other dehulling conditions would help in improving dehulling efficiency and increasing groat yield along with decrease in broken content. This would also be a boon to small and medium scale processors who would be able to produce husk-free whole oat flour to meet demand of the consumer.

\section{ACKNOWLEDGEMENTS}

The financial assistance in the form of Junior Research Fellowship under the Maulana Azad National Fellowship scheme from University Grants Commission, New Delhi, is gratefully acknowledged.

\section{REFERENCES}

[1]. Young V L (1986) Oat lipids and lipid-related enzymes. In: Webster F H (ed) Oats-Chemistry and Technology. American Association of Cereal Chemists St. Paul, MN, USA

[2]. Butt M S, Nadeem M T, Khan M K I, Shabir R and Butt M S (2008) Oat: unique among the cereals. European Journal of Nutrition 47(2): 68-79.

[3]. Gambuś H, Gibiński M, Pastuszka D, Mickowska N, Ziobro R and Witkowicz R (2011) The application of residual oats flour in bread production in order to improve its quality and biological value of protein. ACTA Scientiarum Polonorum 10: 317-25.

[4]. Peltonen-Sainio P, Kontturi M and Rajala A (2004) Impact dehulling oat grain to improve quality of on-farm produced feed. I. Hullability and associated changes in nutritive content and energy value. Agricultural and Food Science. 13: 18-28.

[5]. Doehlert, D C and McMullen, M S (2001) Optimizing conditions for experimental oat dehulling. Cereal Chemistry 78: 675-679.

[6]. Doehlert, D C, McMullen M S and Baumann R R (1999) Factors affecting groat percentage in oat. Crop Science 39: 1858-1865.

[7]. Ganssmann W and Vorwerck K. (1995) Oat milling, processing and storage. In: The oat crop: Production and utilization. Ed R. W. Welch, Chapman and Hall: London, pp 369-408.

[8]. Youngs V L, Peterson D M, and Brown C M (1982) Oats. In: Advances in Cereal Science and Technology Vol. 5, American Association of Cereal Chemists: St. Paul, MN, pp 49-105.

[9]. Gates F, Sontag-Strohm T and Salovaara H (2001) Prosessin vaikutus kaurahiutaleisiin. In: Kaurasta Elinvoimaa. Vol. 1221, Eds H. Salovaara and T. SontagStrohm, Elintarviketeknologian laitos: Helsinki, pp 127-140. [10]. AACC (2000) Approved methods of the AACC, $10^{\text {th }}$ edition. American Association of Cereal Chemists, St. Paul, USA.

[11]. Chakraverty A (1988) Post-harvest technology of cereals, pulses and oilseeds. Oxford and IBH publ Co Pvt Ltd, New Delhi

[12]. Gomez K A and Gomez A A (1984) Statistical Procedures for Agricultural Research. Second Edition. John Wiley and Sons, Canada.

[13]. Doehlert DC and Weissenborn DP (2007) Influence of physical grain characteristics on optimal rotor speed during impact dehulling of oats. Cereal Chemistry 84(3): 294-300.

[14]. Ganssmann W and Vorwerck K (1995) Oat milling, processing and storage. In: The oat crop: Production and Utilization. Ed. R. W. Welch, Chapman and Hall, London, pp 369-408. 
[15]. Webster F H (2002) Whole-grain oats and oat products. In: Whole-grain foods in health and disease. Eds. L. Marquartt, L Slavin and R G Fulcher, American Association of Cereal Chemists, St. Paul, MN, USA.

[16]. Throne J E, Doehlert D C and McMullen M S (2003)

Susceptibility of commercial oat cultivars to Cryptolestes pusillus and Oryrzaephilus surinamensis. Journal of Stored Products Research 39, 213-223.

[17]. Doehlert D C, McMullen M S and Riveland N R (2010) Groat proportion in oats as measured by different methods: Analysis of oats resistant to dehulling and sources of error in mechanical dehulling. Canadian Journal Plant Science 90: 391-397. 